\title{
Relationship between Air Pollution and the Concentration of Nitric Oxide in the Exhaled Air (FeNO) in 8-9-Year-Old School Children in Krakow
}

\author{
Marta Czubaj-Kowal ${ }^{1, *}{ }^{\oplus}$, Ryszard Kurzawa ${ }^{2}{ }^{\infty}$, Henryk Mazurek $^{3}$, Michał Sokołowski ${ }^{1}{ }^{(}$, Teresa Friediger ${ }^{4}$, \\ Maciej Polak ${ }^{5}$ (i) and Grzegorz Józef Nowicki ${ }^{6}$ (D)
}

1 Department of Paediatrics, Stefan Żeromski Specialist Hospital in Krakow, Na Skarpie 66 Str., PL-31-913 Krakow, Poland; mjsokolowski@gmail.com

2 Department of Alergology and Pneumonology, Institute of Tuberculosis and Lung Disorders, Prof. Jana Rudnika 3B Str., PL-34-700 Rabka-Zdrój, Poland; ryszard.kurzawa@gmail.com

3 Department of Pneumonology and Cystic Fibrosis, Institute of Tuberculosis and Lung Disorders, Prof. Jana Rudnika 3B Str., PL-34-700 Rabka-Zdrój, Poland; hmazurek@igrabka.edu.pl

4 Faculty of Health, Catholic University in Ruzomberok, Námestie A. Hlinku 48 Str., SK-034 01 Ruzomberok, Slovakia; t.friediger@gmail.com

5 Department of Epidemiology and Population Studies, Jagiellonian University Medical College, Grzegórzecka 20 Str., PL-31-531 Krakow, Poland; maciej.1.polak@uj.edu.pl

check for updates

Citation: Czubaj-Kowal, M.; Kurzawa, R.; Mazurek, H.; Sokołowski, M.; Friediger, T.; Polak, M.; Nowicki, G.J. Relationship between Air Pollution and the Concentration of Nitric Oxide in the Exhaled Air (FeNO) in 8-9-Year-Old School Children in Krakow. Int. J. Environ. Res. Public Health 2021, 18, 6690. https://doi.org/10.3390/ ijerph18136690

\section{Academic Editors:}

Shyamali Dharmage, Dinh Bui and Gayan Bowatte

\section{Received: 2 May 2021}

Accepted: 20 June 2021

Published: 22 June 2021

Publisher's Note: MDPI stays neutral with regard to jurisdictional claims in published maps and institutional affiliations.

Copyright: (c) 2021 by the authors. Licensee MDPI, Basel, Switzerland. This article is an open access article distributed under the terms and conditions of the Creative Commons Attribution (CC BY) license (https:// creativecommons.org/licenses/by/ $4.0 /)$.
6 Department of Family Medicine and Community Nursing, Medical University of Lublin, Staszica 6 Str., PL-20-081 Lublin, Poland; gnowicki84@gmail.com

* Correspondence: martacz58@gmail.com; Tel.: +48-604-433-428

Abstract: The consequences of air pollution pose one of the most serious threats to human health, and especially impact children from large agglomerations. The measurement of nitric oxide concentration in exhaled air (FeNO) is a valuable biomarker in detecting and monitoring airway inflammation. However, only a few studies have assessed the relationship between FeNO and the level of air pollution. The study aims to estimate the concentration of FeNO in the population of children aged 8-9 attending the third grade of public primary schools in Krakow, as well as to determine the relationship between FeNO concentration and dust and gaseous air pollutants. The research included 4580 children aged 8-9 years who had two FeNO measurements in the winter-autumn and spring-summer periods. The degree of air pollution was obtained from the Regional Inspectorate of Environmental Protection in Krakow. The concentration of pollutants was obtained from three measurement stations located in different parts of the city. The FeNO results were related to air pollution parameters. The study showed weak but significant relationships between FeNO and air pollution parameters. The most significant positive correlations were found for CO8h $(\mathrm{r}=0.1491$, $p<0.001), \mathrm{C}_{6} \mathrm{H}_{6}(\mathrm{r}=0.1420, p<0.001), \mathrm{PM}_{10}(\mathrm{r}=0.1054, p<0.001)$ and $\mathrm{PM}_{2.5}(\mathrm{r}=0.1112, p<0.001)$. We suggest that particulate and gaseous air pollutants impact FeNO concentration in children aged 8-9 years. More research is needed to assess the impact of air pollution on FeNO concentration in children. The results of such studies could help to explain the increase in the number of allergic and respiratory diseases seen in children in recent decades.

Keywords: nitric oxide; FeNO; air pollution; particulate matter; children

\section{Introduction}

Air pollution is one of the most severe global threats in the modern world and impacts, in particular, large urban agglomerations. The World Health Organisation (WHO) reports that 9 out of 10 people in the world breathe polluted air, causing about 7 million deaths per year. In 2016, air pollution led to 4.2 million deaths. During smog alarms, the number of hospitalised patients with myocardial infarction (by 12\%), strokes (by 16\%) and respiratory diseases is increasing. According to WHO, European Union (EU) and UNICEF data, 
Poland, including Krakow, is one of countries with the most polluted air in the EU; in 2016, 33 Polish cities were among the 50 most polluted in Europe. The most frequently monitored components of air pollution in Poland are particulate matter $\left(\mathrm{PM}_{10}, \mathrm{PM}_{2.5}\right)$, carbon monoxide $(\mathrm{CO})$, nitric oxide $(\mathrm{NO})$, and benzene $\left(\mathrm{C}_{6} \mathrm{H}_{6}\right)[1-7]$.

Due to the developmental period, immaturity of the respiratory and immunological system, and detoxification mechanisms, children are most vulnerable to the penetration and concentration of air pollutants in the respiratory tract and to their toxic effects [8-17]. It is estimated that over $90 \%$ of children breathe toxic air every day, 300 million children live in areas with air pollution exceeding 6 times the standard, and 1.7 million children die due to air pollution, including one in 10 children under 5 years of age. Respiratory diseases, including asthma and its exacerbation in school-age children, especially those living in large urban agglomerations with a high level of air pollution, are one of the main causes of school absences, admissions to doctor's offices and hospitalisation [1-4,18,19]. A simple method is needed to assess the impact of air pollution on the inflammation of the airways in children.

The nitric oxide concentration in exhaled air (FeNO), in recent years, due to the simplicity, safety, and non-invasiveness of the FeNO measurement, is increasingly used in the diagnostics of respiratory diseases in children [20-25]. It can be repeated many times in cooperating children. It can be done even in schools and does not require a medical laboratory or special preparation. The result is available immediately, which allows for a quick diagnosis and treatment. Elevated concentrations of nitric oxide in the exhaled air suggest eosinophilic inflammation of the airways. Numerous studies confirm the usefulness of FeNO measurements in the diagnostics, monitoring and treatment of asthma. Some studies suggest its usefulness in diagnostics of allergic rhinitis, chronic cough, eyelash discolouration and COPD [26-43].

However, only a few studies have assessed the impact of air pollution on the result of FeNO measurement in children. Most of these works were based on small patient groups, and only a few reports covered a large group of children [44-49]. As an example, in the study of the paediatric population, Koenig et al. [45] presented 19 children, Delfino et al. [48] 45 children and Permaul et al. [49] 271 children. Only a few researchers examined larger groups of children-Berhane et al. [47] 1211, Idavian et al. [46] 1326 and Zhang et al. [44] 3607. Nevertheless, the relationship between air pollutants and FeNO concentration is not fully understood and documented. Most studies on the effects of exposure to air pollutants related to the increase in FeNO concentration come from Western and Northern Europe [46] and North America [45,47-49]. Poland is characterized by much higher levels of air pollution, especially during winter [50]. The study aims to estimate the concentration of FeNO in the population of children aged 8-9 attending the third grade of public primary schools in Krakow, as well as to determine the relationship between FeNO concentration and dust and gaseous air pollutants.

\section{Materials and Methods}

\subsection{Study Design and Participants}

This population-based study was conducted across all public primary schools within the city of Krakow $(n=119)$. Children aged 8-9 attending the third grade of primary school were included in the investigation. During the research period, in the 2017-2018 school year, 7752 students participated in the third grade of public primary schools in the city of Krakow. The study consisted of two stages (Figure 1). Stage I of the study was carried out during the autumn and winter period, i.e., in the months from October 2017 to January 2018. A total of 5460 children participated in Stage I. Stage II covered the spring and summer months, i.e., May and June 2018, with 4580 children participating. The analyses included 4580 children participating in Stage I and Stage II of the study, which accounted for $83.9 \%$ of children examined in Stage I. The study group accounted for $59.1 \%$ of all children attending the third grade of public primary schools in the city of Krakow. 


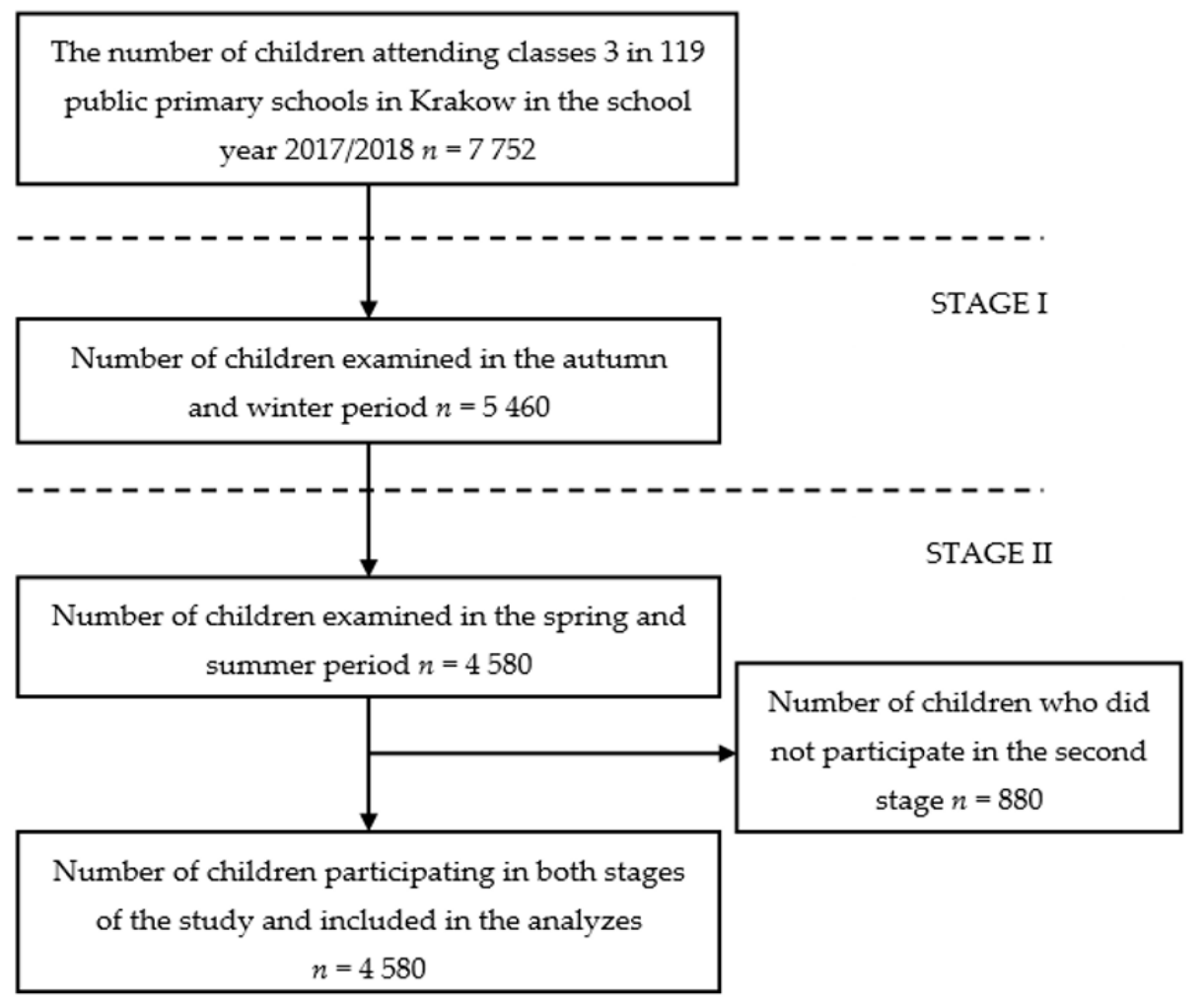

Figure 1. A flow-chart demonstrating the selection of studied groups.

The data collection team included specially trained physicians. They conducted two meetings with the children in each class on two different days. On the first day, the children were given written information explaining the purpose, method of examination, and instructions on how to prepare for the examination. A form for parents/legal guardians to complete, which granted consent for the child's participation in the study, was placed on a separate sheet of paper. The children were asked to present this information to their parents/legal guardians. The information package for parents/legal guardians included e-mail addresses and telephone numbers of the researchers who designed the study, so that parents/legal guardians could easily get in touch and clarify any doubts. On the second day, consent forms signed by the parents/legal guardians were collected from the children. An appropriate examination was then performed with only those children who had provided the signed consent of a parent or legal guardian. The research was carried out in the offices of the school nurse. Both healthy children and children with diagnosed respiratory diseases were included in the study. The presented material is a part of the research project conducted by the Department of Paediatrics, Stefan Żeromski Specialist Hospital in Krakow, Poland, as a part of the campaign to improve air quality, "Let's be together in the fight for clean air in Krakow", conducted by the Municipality of Krakow. The study was approved by the Bioethics Committee Institute of Tuberculosis and Lung Diseases, KB-26/2018.

\subsection{Measurement of FeNO}

The FeNO measurements were taken, according to the recommendation of the American Thoracic Society (ATS) $[35,36,50]$ using the on-line method, with the Hyp'AirFeNO electrochemical analyser (MediSoft, Sorinnes, Belgium). This analyser guaranteed repeatable measurements of $\mathrm{FeNO}$ in the range of 0-600 ppb and did not require external calibration. The electrochemical breath analyser converts gas concentration into electrical signals. Patients exhaled through disposable mouthpieces at a constant flow of $50 \mathrm{~mL} / \mathrm{s}$ for $6 \mathrm{~s}$. The device was calibrated and used according to the manufacturer's instructions and implemented in conjunction with a computer. The ExpAir software provided automatic 
recording of the study, automatic interpretation of results, data logging and a report. This device is easy to use, semi-portable, fast and cheap, compared to other analysers based on the chemiluminescent and laser method. It is characterised by good reliability and repeatability as well as a high level of cooperation with patients, especially children. The test was painless and non-invasive for the paediatric participants.

Two hours prior to testing, the children were to refrain from eating and drinking as well as physical activity, and not to be exposed to tobacco smoke. The tests were carried out between 8:00 a.m. and 2:00 p.m. Before the measurements, the children were instructed on how to perform the test, and the children's ability to perform the procedure was checked. The FeNO measurement was performed twice for each patient. The first measurement was to teach the child how to perform the test, and the second was a diagnostic measurement; this result was retained for subsequent analysis. The FeNO result was presented in ppb values (parts per billion, $10^{-9}$ ), which is a dimensionless description of the ratio of two values. The upper limit or normal value range of the FeNO in children was set at $20 \mathrm{ppb}[21,35,36,51]$.

Concentration values of FeNO above the accepted norm were divided into 3 groups, according to the concentration levels, reflecting the intensity of eosinophilic airways inflammation: Group I, NO 21-50 ppb; Group II, NO 51-99 ppb;and Group III, NO $\geq 100$ ppb [21,28,36,47]. Those intervals corresponded, respectively, to mild, significant and severe eosinophilic inflammation $[33,46]$.

\subsection{Information on Concentration of Ambient Air Pollution}

FeNO levels were correlated with the concentration of ambient air pollution $\mathrm{PM}_{10}$, $\mathrm{PM}_{2.5}$, and $\mathrm{NO}, \mathrm{CO}, \mathrm{C}_{6} \mathrm{H}_{6}$. The degree of air pollution was obtained from the Regional Inspectorate of Environmental Protection in Krakow (http:/ / monitoring.krakow.pios.gov. pl) (accessed on from October 2017 to January 2018 and from May to June 2018). The concentration of pollutants was obtained from 3 measurement stations located in different parts of the city. The concentration values of the studied pollutants were obtained from the monitoring station located closest to the school where the FeNO measurement was performed. The average daily concentration of the analysed contaminants and the median from 7 days preceding the FeNO measurement, which best described the concentration distribution, were taken for analysis.

\subsection{Statistical Analysis}

Continuous variables were presented as means with standard deviation (SD) if normally distributed or median with first quartile (Q1) and third quartile (Q3). The ShapiroWilk test was used to assess conformity with a normal distribution. Categorical variables were reported as absolute numbers and percentages. Differences between groups were assessed with the Chi-square test for categorical variables, and the Mann-Whitney U, $\mathrm{t}$ test and Kruskal-Wallis test for continuous variables. Sperman's rank correlations were used to investigate the relationships between FeNO and $\mathrm{PM}_{10}, \mathrm{PM}_{2.5}, \mathrm{NO}, \mathrm{CO}$, and $\mathrm{C}_{6} \mathrm{H}_{6}$. Moreover, the linear regression was used to consider the influence of age and sexto the relationships between air pollution and FeNO. The analysis of results is presented as a standardized beta coefficient with $95 \%$ confidence intervals (CI). Due to the right-skewed distribution of FeNO, the logarithm transformation was applied. Statistical analyses were conducted using IBM Corp. Released 2017. IBM SPSS Statistics for Windows, Version 25.0. Armonk, NY: IBM Corp. Statistical significance was set at the level $p<0.05$.

\section{Results}

\subsection{Characteristic of Participants}

The age of the children was $8-9$ years, average $8.9(S D=0.48)$. There were slightly more girls than boys in the study group $-2753(50.4 \%)$. 


\subsection{Distribution of Obtained FeNO Measurements}

Table 1 shows the distribution of the obtained FeNO measurements in specific months of the study. In the first measurements, performed in Stage I (autumn-winter period), the FeNO range was from 2 to $144 \mathrm{ppb}$, median $11 \mathrm{ppb}(\mathrm{Q} 1=8, \mathrm{Q} 3=17)$. The FeNO range in the second Stage II (spring-summer period) was from 1 to $196 \mathrm{ppb}$, median $12 \mathrm{ppb}$ $(\mathrm{Q} 1=8, \mathrm{Q} 3=18)$. There were no significant differences in the distribution of FeNO and categories of FeNO between the months in Stage I and Stage II. No significant correlation was observed between the age of the studied children and FeNO values at Stage I $(r=0.02$, $p=0.14$ ). Higher FeNO values were found in boys as compared to girls in both Stages (Stage I: boys median 12, Q1 = 8, Q3 = 18; girls median $11, \mathrm{Q} 1=8, \mathrm{Q} 3=16, p=0.003$; Stage II: boys median 12, Q1=9, Q3 = 19, girls median $11, \mathrm{Q} 1=8, \mathrm{Q} 3=17, p=0.002$ ).

Table 1. The distribution of the measured values of FeNO.

\begin{tabular}{|c|c|c|c|c|c|c|c|c|}
\hline \multicolumn{9}{|c|}{ FeNO (ppb) } \\
\hline Month & $n$ & $\begin{array}{c}\text { Me (Q1-Q3); } \\
\text { Min.-Max }\end{array}$ & $p$ & $\begin{array}{c}0-20 \\
n(\%)\end{array}$ & $\begin{array}{l}21-50 \\
n(\%)\end{array}$ & $\begin{array}{l}51-99 \\
n(\%)\end{array}$ & $\begin{array}{l}\geq 100 \\
n(\%)\end{array}$ & $p$ \\
\hline \multicolumn{9}{|c|}{ Stage I (autumn-winter period): } \\
\hline October & 191 & $\begin{array}{l}11(8-15) ; \\
2-104\end{array}$ & \multirow{4}{*}{$0.14^{\mathrm{A}}$} & $165(86.4)$ & $22(11.5)$ & $3(1.6)$ & $1(0.5)$ & \multirow{4}{*}{$0.068^{\mathrm{C}}$} \\
\hline November & 1883 & $\begin{array}{c}11(7-17) ; \\
2-136\end{array}$ & & $1545(82.1)$ & $292(15.5)$ & $40(2.1)$ & $6(0.3)$ & \\
\hline December & 1673 & $\begin{array}{c}12(8-17) \\
2-144\end{array}$ & & $1374(82.3)$ & $231(13.8)$ & $56(3.1)$ & $12(0.8)$ & \\
\hline January & 833 & $\begin{array}{c}11(8-16) ; \\
4-125\end{array}$ & & $704(84.5)$ & $104(12.5)$ & $23(2.6)$ & $2(0.4)$ & \\
\hline \multicolumn{9}{|c|}{ Stage II (springer-summer period): } \\
\hline May & 2279 & $\begin{array}{c}12(9-18) ; \\
1-154\end{array}$ & \multirow{2}{*}{$0.23^{\mathrm{B}}$} & $1832(80.4)$ & $365(16.0)$ & $74(3.3)$ & $8(0.4)$ & \multirow{2}{*}{$0.15^{C}$} \\
\hline June & 2301 & $\begin{array}{c}11(8-18) \\
1-196\end{array}$ & & $1796(78.0)$ & 400 (17.4) & $98(4.3)$ & $7(0.3)$ & \\
\hline
\end{tabular}

Me: median; Q1: lower quartile; Q3: upper quartile; ${ }^{A} p$-values calculated using Kruskal-Wallis test; ${ }^{\mathrm{B}} p$-values calculated using Mann-Whitney test; ${ }^{\mathrm{C}} p$-values calculated using chi-square.

\subsection{The Level of Air Pollution on The Days of FeNO Measurements}

The level of air pollution in the range: particulate matter (PM) in two size fractions $\mathrm{PM}_{10}, \mathrm{PM}_{2.5}$, nitric oxide (NO), benzene $\left(\mathrm{C}_{6} \mathrm{H}_{6}\right)$ and carbon monoxide $(\mathrm{CO})$ on the days of FeNO measurements of Stage I and II is shown in Table 2.

\subsection{Relationship Between FeNO and Air Pollution}

Table 3 shows the relationship between the FeNO and the air pollution measured on the day of measurement, and the median value from the week before. We observed a significant positive relationship between $\mathrm{FeNO}$ and the value of air pollutants $\mathrm{PM}_{10}$, $\mathrm{PM}_{2.5}, \mathrm{NO}, \mathrm{CO}$ and $\mathrm{C}_{6} \mathrm{H}_{6}$ in Stage I and for $\mathrm{NO}, \mathrm{CO}$ and $\mathrm{PM}_{2.5}$ (only for concentration from the day of the FeNO test) in Stage II. In both Stages correlations of FeNO results with pollutants concentration were stronger for measurement from the day of examination than for median from the last 7 days. The strongest relationships were found for parameters $\operatorname{CO8h}(\mathrm{r}=0.149 ; p<0.001), \mathrm{C}_{6} \mathrm{H}_{6}(\mathrm{r}=0.143 ; p<0.001)$ and $\mathrm{PM}_{2.5}(\mathrm{r}=0.106 ; p<0.001)$ in Stage I. After adjustment for age andsex, the results were similar to those obtained in the univariable analysis and remained significant. The results of the multivariable linear regression are presented in Supplementary Materials Table S1. 
Table 2. The value of air pollution during the period under investigation.

\begin{tabular}{|c|c|c|c|c|c|}
\hline Stage/Month & $\mathrm{NO}\left(\mu \mathrm{g} / \mathrm{m}^{3}\right)$ & $\operatorname{CO8h}\left(\mu \mathrm{g} / \mathrm{m}^{3}\right)$ & $\mathrm{C}_{6} \mathrm{H}_{6}\left(\mu \mathrm{g} / \mathrm{m}^{3}\right)$ & $\mathrm{PM}_{10}\left(\mu \mathrm{g} / \mathrm{m}^{3}\right)$ & $\mathrm{PM}_{2.5}\left(\mu \mathrm{g} / \mathrm{m}^{3}\right)$ \\
\hline \multicolumn{6}{|c|}{ Stage I (autumn-winter period): } \\
\hline & $\begin{array}{c}45(14-91) \\
1-331\end{array}$ & $\begin{array}{c}1063(744-1501) \\
343-3250\end{array}$ & $\begin{array}{c}2(1.2-3.9) \\
0.4-25.4\end{array}$ & $\begin{array}{l}43(26-67) \\
\quad 7-192\end{array}$ & $\begin{array}{c}31(18-51) \\
4-163\end{array}$ \\
\hline October & $\begin{array}{c}32(14-78) \\
1-181 \\
\end{array}$ & $\begin{array}{c}834 \text { (658-1093); } \\
353-1588 \\
\end{array}$ & $\begin{array}{c}1(1.0-2.2) \\
0.6-3.5 \\
\end{array}$ & $\begin{array}{c}30(21-50) \\
7-107 \\
\end{array}$ & $\begin{array}{c}22(13-37) \\
4-79 \\
\end{array}$ \\
\hline November & $\begin{array}{c}55(20-115) \\
2-278\end{array}$ & $\begin{array}{c}1247(919-1907.5) \\
365-3080\end{array}$ & $\begin{array}{c}3(1.6-4.0) \\
0.7-5.4\end{array}$ & $\begin{array}{c}48(29-75) \\
13-127\end{array}$ & $\begin{array}{c}34(22-57) \\
7-93\end{array}$ \\
\hline December & $\begin{array}{l}45(14-83) \\
2-202\end{array}$ & $\begin{array}{c}1072(772-1498) \\
343-2016\end{array}$ & $\begin{array}{c}2(1.3-3.1) \\
0.5-7.0\end{array}$ & $\begin{array}{l}44(29-65) \\
12-121\end{array}$ & $\begin{array}{c}30(20-50) \\
5-111\end{array}$ \\
\hline January & $\begin{array}{c}38(10-107) \\
1-331\end{array}$ & $\begin{array}{c}1202(820-1624) \\
467-3250\end{array}$ & $\begin{array}{c}3(1.9-5.5) \\
0.4-25.4\end{array}$ & $\begin{array}{c}53(32-76) \\
13-192\end{array}$ & $\begin{array}{c}40(21-62) \\
7-163\end{array}$ \\
\hline \multicolumn{6}{|c|}{ Stage II (spring-summer period): } \\
\hline & $\begin{array}{c}12(4-47) ; \\
0-108\end{array}$ & $\begin{array}{c}627(527-741) \\
234-1185\end{array}$ & $\begin{array}{c}1(0.4-1.4) \\
0.2-2.9\end{array}$ & $\begin{array}{c}28(22-37) \\
\quad 9-59\end{array}$ & $\begin{array}{c}17(13-21) \\
\quad 4-39\end{array}$ \\
\hline May & $\begin{array}{l}13(4-41) \\
0-99\end{array}$ & $\begin{array}{c}666(532-741) \\
234-899\end{array}$ & $\begin{array}{c}1(0.5-1.7) \\
0.2-2.9\end{array}$ & $\begin{array}{c}30(24-40) \\
12-59\end{array}$ & $\begin{array}{c}17(13-21) \\
\quad 7-39\end{array}$ \\
\hline June & $\begin{array}{c}8(4-50) \\
0-108\end{array}$ & $\begin{array}{c}612(475-724) \\
330-1185\end{array}$ & $\begin{array}{c}1(0.4-1.2) \\
0.2-2.1\end{array}$ & $\begin{array}{l}27(22-35) \\
\quad 9-52\end{array}$ & $\begin{array}{c}16(4-35) \\
11-21\end{array}$ \\
\hline
\end{tabular}

Date are presented as: Me (Q1-Q3); Min.-Max.

Table 3. Relationship between FeNO and air pollution in the study group.

\begin{tabular}{|c|c|c|c|c|}
\hline \multirow{2}{*}{ FeNO } & \multicolumn{2}{|c|}{ Stage I (Autumn-Winter Period): } & \multicolumn{2}{|c|}{ Stage II (Spring-Summer Period): } \\
\hline & $\mathbf{r}$ & $p$ & $\mathbf{r}$ & $p$ \\
\hline \multicolumn{5}{|c|}{ The day of measurement: } \\
\hline $\mathrm{NO}\left(\mu \mathrm{g} / \mathrm{m}^{3}\right)$ & 0.053 & $<0.001$ & 0.031 & 0.035 \\
\hline $\operatorname{CO} 8 \mathrm{~h}\left(\mu \mathrm{g} / \mathrm{m}^{3}\right)$ & 0.149 & $<0.001$ & 0.067 & $<0.001$ \\
\hline $\mathrm{C}_{6} \mathrm{H}_{6}\left(\mu \mathrm{g} / \mathrm{m}^{3}\right)$ & 0.143 & $<0.001$ & 0.016 & 0.271 \\
\hline $\mathrm{PM}_{10}\left(\mu \mathrm{g} / \mathrm{m}^{3}\right)$ & 0.097 & $<0.001$ & 0.027 & 0.065 \\
\hline $\mathrm{PM}_{2.5}\left(\mu \mathrm{g} / \mathrm{m}^{3}\right)$ & 0.106 & $<0.001$ & 0.039 & 0.022 \\
\hline \multicolumn{5}{|c|}{ The median value from the week before: } \\
\hline $\mathrm{NO}\left(\mu \mathrm{g} / \mathrm{m}^{3}\right)$ & 0.028 & 0.016 & 0.051 & $<0.001$ \\
\hline $\operatorname{CO} 8 \mathrm{~h}\left(\mu \mathrm{g} / \mathrm{m}^{3}\right)$ & 0.057 & $<0.001$ & 0.056 & 0.001 \\
\hline $\mathrm{C}_{6} \mathrm{H}_{6}\left(\mu \mathrm{g} / \mathrm{m}^{3}\right)$ & 0.043 & 0.018 & 0.024 & 0.106 \\
\hline $\mathrm{PM}_{10}\left(\mu \mathrm{g} / \mathrm{m}^{3}\right)$ & 0.053 & $<0.001$ & 0.012 & 0.417 \\
\hline $\mathrm{PM}_{2.5}\left(\mu \mathrm{g} / \mathrm{m}^{3}\right)$ & 0.044 & $<0.001$ & 0.002 & 0.899 \\
\hline
\end{tabular}

\section{Discussion}

Our analysis of FeNO measurements made in a large group of children in Krakow showed a correlation between FeNO values and concentrations of air pollutants. The most significant positive correlations occurred for $\mathrm{CO} 8 \mathrm{~h}, \mathrm{C}_{6} \mathrm{H}_{6}, \mathrm{PM} 10$ and PM2.5. Higher values of these parameters were associated with higher FeNO concentration values. It concerns both the concentration of air pollution parameters on the day of FeNO measurements and the median from 7 days before measurements were taken. The relationship described above was stronger in the autumn and winter period.

FeNO is a non-invasive biomarker with good repeatability of measurements, high specificity and sensitivity in diagnosing, monitoring or predicting responses to respiratory 
diseases [52]. Several epidemiological studies suggest a change in FeNO in the assessment of airway inflammation in association with air pollution, thus suggesting that short-term or long-term exposure to air pollution may be associated with alteration in FeNO. However, the research results remain inconsistent. Zhang et al. [53] found that an increase in $\mathrm{PM}_{2.5}$ by $10 \mu \mathrm{g} / \mathrm{m}^{3}$ was associated with an increase in FeNO by $2.59 \%$. In studies by Zhao et al. [54], carried out in a healthy population, it was found that an increase in $\mathrm{NO}_{2}$ of $10 \mu \mathrm{g} / \mathrm{m}^{3}$ was associated with a $10.58 \%$ increase in FeNO. Similar results were reported in the population of people with COPD. Conversely, several studies showed that air pollution was not related to FeNO levels [55-58]. However, a meta-analysis of 27 studies by Chen et al. [59] on the impact of air pollution on FeNO levels in adults and children revealed that an increase in short-term exposure to $\mathrm{PM}_{10}, \mathrm{PM}_{2.5}, \mathrm{NO} 2$ and $\mathrm{SO} 2$ by $10 \mu \mathrm{g} / \mathrm{m}^{3}$ was associated with an increase in FeNO concentration by 3.2\%, 2.25\%, 4,9\% and 8.28\% (95\% CI: 3.61\%, 12.59\%). Moreover, another meta-analysis by Khreis et al. showed that the onset of asthma was significantly associated with an increase in $\mathrm{PM}_{2.5}$ concentration by $1 \mu \mathrm{g} / \mathrm{m}^{3}$ in the air, by $2 \mu \mathrm{g} / \mathrm{m}^{3}$ for $\mathrm{PM}_{10}$ and by $4 \mu \mathrm{g} / \mathrm{m}^{3}$ for $\mathrm{NO} 2$.

During our own research during the autumn-winter period, we observed significant positive relationships between FeNO and air pollution parameters $\mathrm{PM}_{10}, \mathrm{PM}_{2.5}, \mathrm{NO}, \mathrm{CO}$ h, and $\mathrm{C}_{6} \mathrm{H}_{6}$. In the spring-summer period, air pollution in Krakow was lower than in the autumn-winter period, and we observed weaker relationships between FeNO and air pollution parameters. Significant positive relationships were found only in the case of $\mathrm{CO} 8 \mathrm{~h}, \mathrm{NO}$ for the concentration on the day of the FeNO measurement and for the medians 7 days before the test, and $\mathrm{PM}_{2.5}$ for the measurement on that day. Higher values of FeNO measured at Phase II compared to Phase I despite the reduced exposure to air pollutants may be related to high exposure to pollens in the spring-summer period. However, this aspect was not analysed in this study. A stronger correlation was found between the FeNO concentration and the median $\mathrm{PM}_{2.5}$ concentration from the last 7 days than in the case of PM10, which is consistent with the results of the studies by MacIntyre et al. [60] who concluded that $\mathrm{PM}_{2.5}$ is possibly more harmful to the respiratory system than $\mathrm{PM}_{10}$. The same result was obtained by Zhang et al. [61] in a group of five-year-old children.

Most of the published studies on the impact of air pollutants on FeNO were completed in different study settings and in small groups of children-often selected by health status. Steerenberg et al. [62] were the first to describe a longitudinal observation of 82 children exposed to air pollution. Short-term exposure resulted in increases in FeNO levels, increased inflammatory, nasal markers and PEF changes. Delfino et al. [48] in a study of 45 schoolchildren with asthma showed a positive correlation between the two-day mean concentration of pollutants and FeNO. In two-pollutant models, the most significant correlation was found for elemental carbon (EC) and $\mathrm{NO}_{2}$. Koenig et al. [45] published a work on a small group of 19 children with asthma, aged 6-13 years. They demonstrated a relationship between FeNO and $\mathrm{PM}_{2.5}$ exposure in both winter and summer, with 10-day measurements taken at home or outdoors, from personal monitors and three central-site monitors.

Only a few studies included large groups of children. Berhane et al. [47] analysed the results of 2240 schoolchildren from Southern California, aged 7-9 years. They showed that short-term increases in air pollutant concentrations $\left(\mathrm{PM}_{2.5}, \mathrm{PM}_{10}\right.$ and ozone $\left(\mathrm{O}_{3}\right)$ ) were significantly related to higher FeNO levels-independently of asthma and allergy status. They suggested that air pollution increases nitrosative stress in both healthy and atopic children. Idavain et al. [46] studied a group of 1326 schoolchildren from Estonia aged 8-12 years, living near oil processing factories. In a cross-sectional study, they showed that children exposed to higher levels of industry-specific air pollutants had significantly increased prevalence of high values of FeNO, respiratory symptoms and asthma. Children exposed to higher concentrations of $\mathrm{C}_{6} \mathrm{H}_{6}$ had a higher odds ratio (OR) of having FeNO levels $\geq 30 \mathrm{ppm}$.

In the presented own research, no correlation was observed between the age of the examined children and FeNO values in the autumn-winter period, and a weak correlation was observed in the spring-summer period. It could be explained by the narrow age range 
of the examined children, which was very similar. In both study periods, autumn-winter and spring-summer, we observed higher FeNO values in boys than in girls. There is controversy in the literature about sex differences in FeNO: similar to us, most researchers observed higher values in boys $[25,41]$, but in other studies, the difference was not significant $[24,44]$.

There are several potential mechanisms explaining the relationship between air pollution and FeNO concentration. In the case of PM, the mechanism of changes in the lungs can be explained as follows. Nitric oxide is produced by many cells and is generated through the amino acid L-arginine by nitric oxide synthase (NOS) [63]. NOS exists in three different isoforms: neuronal (nNOS), induced (iNOS) and endothelial (eNOS). Of the above-mentioned forms, iNOS appears to be a pro-inflammatory mediator and is associated with inflammatory diseases of the respiratory tract. Inhaled PM may penetrate the lining of epithelial cells, increasing L-arginine oxidation and activating lipid peroxidation [52]. This process influences the increased production of $\mathrm{NO}$ under oxidative stress conditions, which secondarily generates strong oxidation reactions $[63,64]$. The mechanism underlying the impact of gaseous pollutants in the air on FeNO concentration is probably modulated by DNA methylation in the arginase-nitric oxide synthesis pathway [65]. Studies on human vascular endothelial cells showed that hypomethylation of NOS2A can lead to an increase in FeNO by increasing the concentration of iNOS. Moreover, ARG2 hypomethylation may also increase FeNO levels by increasing the availability of L-arginase [66].

Growing evidence suggests a link between ozone $\left(\mathrm{O}_{3}\right)$ concentration and respiratory disease $[67,68]$, but it is the major photochemical pollutant and strong oxidant that has not attracted the attention of many researchers. Several animal studies investigated the relationship between ozone exposure and FeNO. Niu et al. [69] showed that ozone can cause a decrease in NOS2A methylation and increase induced NOS expression, suggesting that inhalation of ozone may affect DNA methyltransferases. The authors hypothesized that increased FeNOlevels are also associated with decreased arginase concentration and increased arginase- 2 methylation. Studies on $\mathrm{O} 3$ exposure and increased FeNO concentration in children and adolescents produced different results. Barraza-Villarreal et al. [70], Nickmilder et al. [71], and Karakatsani et al. [72] observed a positive relationship between ozone exposure and FeNO. On the other hand, Altuğ et al. [73] and Barath et al. [74] did not confirm the influence of $\mathrm{O}_{3}$ on the FeNO level. Our research did not assess the impact of $\mathrm{O}_{3}$ on the FeNO level because only one measuring station within the city of Krakow (located at Bujaka Street) provides information on the concentration of $\mathrm{O}_{3}$.

The study of FeNO and its correlation with air pollution is of clinical importance for the early detection of eosinophilic airway inflammation, especially in children living in highly polluted areas. It allows selecting a group of children with inflammatory lesions and the risk of damaging the respiratory tract that requires further diagnostics. FeNO measurement is simple, cheap, non-invasive, and easy to perform, even for the youngest children. The assessment of the correlation of FeNO with air pollution draws attention to the impact of environmental pollution on the health of children. It prompts taking actions to protect the environment, which translates into the improvement of the health of the society. The clinical importance of FeNO measurement in the detection of eosinophilic inflammation of the airways, diagnosis, treatment, and its modification in bronchial asthma [26-43], as well as correlation with air pollution, is confirmed by many authors [44-49]. FeNO correlates well with other indicators of eosinophilic inflammation assessed, e.g., in the biopsy material, bronchoalveolar lavage fluid, or induced sputum [21,28]. However, these methods are invasive, time-consuming, expensive, and difficult to perform in children. As a population-level study, our study was designed to demonstrate the relationship of FeNO levels with air pollution. Further studies are needed to evaluate the correlation between FeNO and air pollutants, taking into account individual measurements of exposure to air pollution and considering confounding variables to more accurately demonstrate the relationship and utility at the clinical level. Allergic diseases, asthma, allergic rhinitis, atopic dermatitis, exposure to animal and pollen allergens, exposure to tobacco smoke, 
infection frequency, distance from pollutant emission sources, age, gender, chronic diseases, and immunization should be taken into account-these are socioeconomic factors.

It is worth considering the strengths and weaknesses of this study. An extensive analysis of the literature suggests that this is the first study in which such a large group of children in Poland participated. Secondly, the study included 4580 children living in the second largest city in Poland, which is characterised by some of the most severe pollution in Poland and Europe [1-3]. Thirdly, the study covered a group of children attending public primary schools in the city of Krakow, and this city is characterised by the most polluted air in Poland and Europe.

Nevertheless, this study has several limitations. First, it is a cross-sectional study and, therefore, shows no cause-effect or time-effect relationship between FeNO concentration and air pollution. Secondly, only the basic sociodemographic data of the surveyed children (i.e., sex and age) were considered. We did not gather any information on the influence of other sociodemographic variables, such as lifestyle (e.g., exposure to tobacco smoke), the occurrence of respiratory diseases (such as bronchial asthma, atopy, inhalation allergies, etc.) and the medications taken; these features may influence the relationship between air pollution and FeNO concentration. Therefore, no detailed analyses of the influence of these variables on the FeNO concentration were performed. These additional factors, as well as allergy to trees or grass pollens and possible asthma exacerbations probably had an impact on the higher FeNO values during spring-summer in some of the examined children; however, passive exposure to tobacco smoke may lead to a decrease in FeNO concentration $[75,76]$. Third, the information on air pollution (obtained from air quality monitoring stations) may not match the actual air pollution exposure for a particular child. The assumed values of exposure levels to air pollution could cause the relationships to be biased. However, the natural topography of the basin in which Krakow is located results in accumulation and maintenance of the level of air pollution in Krakow with relatively uniform distribution within the city $[77,78]$. Moreover, in order for the air pollution monitoring data to best reflect the actual exposure to pollutants of the studied children, in the exposure assessment, we chose the monitoring stations closest to the school where we conducted the research (mean distance was equal to $3.1 \mathrm{~km}(S D=1.5)$ ).

\section{Conclusions}

Air pollution positively correlates with FeNO concentration in children aged 8-9 years. Although in our research this correlation was weak, it was important for dust and gaseous pollutants. More research is needed to assess the impact of air pollution on FeNO concentration, taking into account confounding variables, such as the sociodemographic and medical variables of respondents. The results of such studies could help explain the increase in the number of allergic and respiratory diseases seen in children in recent decades.

Supplementary Materials: The following are available online at https://www.mdpi.com/article/10 .3390/ijerph18136690/s1. Table S1: Relationship between FeNO and air pollution in the study group after adjustment for age and sex.

Author Contributions: M.C.-K. developed the concept of the study, M.C.-K. and M.P. analysed the data and contributed to its interpretation, M.C.-K., R.K. and G.J.N. interpreted the data and wrote the original draft. M.C.-K., H.M., M.S. and G.J.N. were involved in writing, reviewing and editing the manuscript, M.C.-K., R.K., H.M., M.S., G.J.N., T.F. were responsible for funding acquisition and supervision. All authors were involved in critically revising the manuscript and have given their approval to the manuscript submitted. All authors have read and agreed to the published version of the manuscript.

Funding: The presented material is a part of a research project conducted by the Paediatric Department of the Stefan Żeromski Specialist Hospital in Krakow, Poland as part of the campaign to improve air quality "Let's be together in the fight for clean air in Krakow" conducted by the Municipality of Krakow. 
Institutional Review Board Statement: The study was conducted according to the guidelines of the Declaration of Helsinki and approved by the Bioethics Committee Institute of Tuberculosis and Lung Diseases, KB-26/2018.

Informed Consent Statement: Informed consent was obtained from parents or legal guardians of the children participating in the study.

Data Availability Statement: The data are available from the corresponding author upon reasonable request.

Conflicts of Interest: The authors declare no conflict of interest.

\section{References}

1. World Health Organization. Ambient Air Pollution: A Global Assessment of Exposure and Burden of Disease. 2016. Available online: http:/ / www.who.int/phe/publications/air-pollution-global-assessment/en/ (accessed on 20 October 2020).

2. UNICEF. Clear the Air for Children. 2016. Available online: https://www.unicef.org/publications/index_92957.html (accessed on 20 October 2020).

3. World Health Organization. Noncommunicable Diseases and Air Pollution. WHO European High-Level Conference on Noncommunicable Diseases. Available online: https:/ /www.euro.who.int/_data/assets/pdf_file/0005/397787/Air-Pollutionand-NCDs.pdf (accessed on 20 October 2020).

4. Jędrak, J.; Konduracka, E.; Badyga, A.J.; Dąbrowiecki, P. Wpływ Zanieczyszczeń Powietrza na Zdrowia; Stowarzyszenie Krakowski Alarm Smogowy: Krakow, Poland, 2017.

5. European Environment Agency. Air quality standards. EEA. 2017. Available online: https://www.eea.europa.eu/themes/air/ explore-air-pollution-data (accessed on 20 October 2020).

6. Biuro, ds. Ochrony Zdrowia Urzędu Miasta Krakowa. Raport o Zdrowiu Mieszkańców Miasta Krakowa i jego Uwarunkowaniach. Krąów, 2016 Ministerstwo Zdrowia. Mapa Potrzeb Zdrowotnych dla Polski. Available online: http:/ /www.mpz.mz.gov.pl (accessed on 20 October 2020).

7. International Energy Agency. Energyand Air Pollution. World Energy Outlook Special Report. 2016. Available online: https:// www.iea.org/publications/freepublications/publication/WorldEnergyOutlookSpecialReport2016EnergyandAirPollution.pdf (accessed on 20 October 2020).

8. Carlsten, C. Air pollution and children's respiratory health. Can. Respir. J. 2015, 22, 256. [CrossRef]

9. Madsen, C.; Haberg, S.E.; Magnus, M.C.; Aamodt, G.; Stigum, H.; London, S.J.; Nystad, W.; Nafstad, P. Pregnancy exposure to air pollution and early childhood respiratory health in the Norwegian Motherand Child Cohort Study (MoBa). BMJ Open. 2017, 7, e015796. [CrossRef] [PubMed]

10. Koranteng, S.; Vargas, A.R.; Buka, I. Ambient air pollution and children's health: A systematic review of Canadian epidemiological studies. Paediatr. Child. Health. 2007, 12, 225-233. [PubMed]

11. Sublett, J.L. Effectiveness of air filters and air cleaners in allergic respiratory diseases: A review of the recent literature. Curr. Allergy Asthma Rep. 2011, 11, 395-402. [CrossRef]

12. Stern, D.A.; Morgan, W.J.; Wright, A.L.; Guerra, S.; Martinez, F.D. Poor airway function in early infancy and lung function by age 22 years: A non-selective longitudinal cohort study. Lancet 2007, 370, 758-764. [CrossRef]

13. Johansson, C.; Lövenheim, B.; Schantz, P.; Wahlgren, L.; Almström, P.; Markstedt, A.; Strömgren, M.; Forsberg, B.; Sommar, J.N. Impacts on air pollution and health by changing commuting from car to bicycle. Sci. Total Environ. 2017, 584-585, 55-63. [CrossRef]

14. Kowalska, M.; Skrzypek, M.; Kowalski, M.; Cyrys, J.; Ewa, N.; Czech, E. The Relationship between Daily Concentration of Fine Particulate Matterin Ambient Air and Exacerbation of Respiratory Diseases in Silesian Agglomeration, Poland. Int. J. Environ. Res. Public Health. 2019, 16, 1131. [CrossRef] [PubMed]

15. Holt, P.G.; Jones, C.A. The development of the immune system during pregnancy and early life. Allergy 2000, 55, 688-697. [CrossRef] [PubMed]

16. Rurarz, A.; Feleszko, W. Smog: Nowe zagrożenie w chorobach układu oddechowego dla dzieci oraz metody unikania jego skutków—praktycznie. Terapia 2017, 11, 53-56.

17. Health Effects Institute. Understanding the Health Effects of Ambient Ultrafine Particles. 2013. HEI Review Panel on Ultrafine Particles. HEI Perspectives 3. Available online: http:/ / pubs.healtheffects.org/view.php?id=394 (accessed on 20 October 2020).

18. Chauhan, A.J.; Johnston, S.L. Air pollution and infection in respiratory illness. Br. Med. Bull. 2003, 68, 95-112. [CrossRef]

19. Malec, K.; Bednarek, M.; Bartkiewicz-Skrabania, P.; Piórkowska, P. The impact of particulate matter (PM2.5, PM10) concentration on the occurrence of acute cardiorespiratory disorders and its exacerbations in children in Krakow agglomeration on the basis of Admission to the Voivodship Children Specialist Hospitalin Krakow. Nowa Pediatr. 2016, 4, 168-173.

20. Ziętkowski, Z.; Siepko, R.; Czarniakowska-Bołuć, M.; Budny, W.; Łukaszyk, M.; Skiepko, U.; Bodzenta-Łukaszyk, A. The usefulness of exhaled nitric oxide in monitoring of treatment in patients with severe asthma. Alerg. Astma Immunilogia 2013, 18, 114-117. 
21. Kłak, A.; Krzych-Fałta, E.; Samoliński, B. The role of nitric oxide in the inflamed airways. Alerg. Astma Immunilogia 2013, 18, 91-96.

22. Taylor, D.R. Nitric oxide as a clinical guide for asthma management. J. Allergy Clin. Immunol. 2006, 117, 259-262. [CrossRef]

23. Sánchez-García, S.; Habernau Mena, A.; Quirce, S. Biomarkers in inflammometry pediatric asthma: Utility in daily clinical practice. Eur. Clin. Respir. J. 2017, 4, 1356160. [CrossRef]

24. Rachel, M.; Biesiadecki, M.; Aebisher, D.; Galiniak, S. Exhaled nitric oxide in pediatric patients with respiratory disease. J. Breath Res. 2019, 13, 046007. [CrossRef] [PubMed]

25. Wong, G.W.; Liu, E.K.; Leung, T.F.; Yung, E.; Ko, F.W.; Hui, D.S.; Fok, T.F.; Lai, C.K. High levels and gender difference of exhaled nitric oxide in Chinese schoolchildren. Clin. Exp. Allergy 2005, 35, 889-893. [CrossRef]

26. Mierzejewska, A.; Jodłowska, M.; Kućko, A.; Rybak, K.; Sołtysiak, M.; Sroka, S.; Kalicki, B. Usefulness of determining exhaled nitric oxide levels for the assessment of asthma severity in children. Pediatr. Med. Rodz. 2015, 11, 186-196. [CrossRef]

27. Alving, K.; Weitzberg, E.; Lundberg, J.M. Increased amount of nitric oxide in exhaled air of asthmatics. Eur. Respir. J. 1993, 6, 1368-1370.

28. Ziętkowski, Z.; Ziętkowska, E.; Bodzenta-Łukaszyk, A. Exhaled nitric oxide measurements in the diagnosis of respiratory diseases. Alerg. Astma Immunol. 2009, 14, 215-222.

29. Kharitonov, S.A.; Yates, D.; Robbins, R.A.; Logan-Sinclair, R.; Shinebourne, E.A.; Barnes, P.J. Increased nitric oxide in exhaled air of asthmatic patients. Lancet 1994, 343, 133-135. [CrossRef]

30. Silvestri, M.; Spallarossa, D.; Frangova Yourukova, V.; Battistini, E.; Fregonese, B.; Rossi, G.A. Orally exhaled nitric oxide levels are related to the degree of blood eosinophilia in atopic children with mild-intermittent asthma. Eur. Respir. J. 1999, 13, 321-326. [CrossRef] [PubMed]

31. Lanz, M.J.; Leung, D.Y.; McCormick, D.R.; Harbeck, R.; Szefler, S.J.; White, C.W. Comparison of exhaled nitric oxide, serum eosinophilic cationic protein, and soluble interleukin-2 receptor in exacerbations of pediatric asthma. Pediatr. Pulmonol. 1997, 24, 305-311. [CrossRef]

32. Mattes, J.; Stormvan's Gravesande, K.; Reining, U.; Alving, K.; Ihorst, G.; Henschen, M.; Kuehr, J. NO in exhaled air is correlated with markers of eosinophilic airway inflammation in corticosteroid-dependent childhood asthma. Eur. Respir. J. 1999, 13, 1391-1395. [PubMed]

33. Petsky, H.L.; Kew, K.M.; Chang, A.B. Exhaled nitric oxide levels to guide treatment for children with asthma. Cochrane Database Syst. Rev. 2016, 11, CD011439. [CrossRef] [PubMed]

34. Dadas-Stasiak, E.; Jung, A.; Jobs, K.; Kalicka, B. An assessment of fractional exhaled nitric oxide in children with allergic rhinitis. Pediatr. Med. Rodz. 2016, 12, 285-295. [CrossRef]

35. American Thoracic Society; European Respiratory Society. ATS/ERS recommendations for standardized procedures for the online and offline measurement of exhaled lower respiratory nitric oxide and nasal nitric oxide, 2005. Am. J. Respir. Crit. Care. Med. 2005, 171, 912-930. [CrossRef] [PubMed]

36. Dweik, R.A.; Boggs, P.B.; Erzurum, S.C.; Irvin, C.G.; Leigh, M.W.; Lundberg, J.O.; Olin, A.C.; Plummer, A.L.; Taylor, D.R.; American Thoracic Society Committee on Interpretation of Exhaled Nitric Oxide Levels (FENO) for Clinical Applications. An official ATS clinical practice guideline: Interpretation of exhaled nitric oxide levels (FENO) for clinical applications. Am. J. Respir. Crit. Care. Med. 2011, 184, 602-615. [CrossRef] [PubMed]

37. Ducharme, F.M.; Dell, S.D.; Radhakrishnan, D.; Grad, R.M.; Watson, W.T.; Yang, C.L.; Zelman, M. Diagnosis and management of asthma in preschoolers: A Canadian Thoracic Society and Canadian Paediatric Society position paper. Paediatr. Child. Health. 2015, 20, 353-371. [CrossRef]

38. British Thoracic Society. BTS/SIGN British guideline on the management of asthma 2016. Available online: https:/ /www.britthoracic.org.uk/document-library/clinical-information/asthma/btssign-asthma-guideline-2016/ (accessed on 20 October 2020).

39. Karrasch, S.; Linde, K.; Rücker, G.; Sommer, H.; Karsch-Völk, M.; Kleijnen, J.; Jörres, R.A.; Schneider, A. Accuracy of FENO for diagnosing asthma: A systematic review. Thorax 2017, 72, 109-116. [CrossRef]

40. Gjurow-Podlecki, D.; Majak, P.; Kałuzińska-Parzyszek, I.; Jerzyńska, J.; Stelmach, I. Fractional exhaled nitric oxide correlates with FEV1 in bronchial reversibility test in children with asthma. Alerg. Astma Immunol. 2010, 15, $203-207$.

41. Woo, S.I.; Lee, J.H.; Kim, H.; Kang, J.W.; Sun, Y.H.; Hahn, Y.S. Utility of fractional exhaled nitric oxide (F(E)NO) measurements in diagnosing asthma. Respir. Med. 2012, 106, 1103-1109. [CrossRef]

42. Katial, R.; Stewart, L. Exhaled nitric oxide: A test for diagnosis and control of asthma? Curr. Allergy Asthma Rep. 2007, 7, 459-463. [CrossRef] [PubMed]

43. Gan, W.Q.; FitzGerald, J.M.; Carlsten, C.; Sadatsafavi, M.; Brauer, M. Associations of ambient air pollution with chronic obstructive pulmonary disease hospitalization and mortality. Am. J. Respir. Crit. Care Med. 2013, 187, 721-727. [CrossRef] [PubMed]

44. Zhang, Y.; Berhane, K.; Eckel, S.P.; Muchmore, P.; Molshatzki, N.B.-A.; Rappaport, E.B.; Linn, W.S.; Habre, R.; Gilliland, F.D. Adverse effects of annual fluctuations in air pollution on feno in children: A longitudinal study. Am. J. Respir. Crit. Care Med. 2020, 201, A1020.

45. Koenig, J.Q.; Jansen, K.; Mar, T.F.; Lumley, T.; Kaufman, J.; Trenga, C.A.; Sullivan, J.; Liu, L.J.; Shapiro, G.G.; Larson, T.V. Measurement of offline exhaled nitric oxide in a study of community exposure to air pollution. Environ. Health. Perspect. 2003, 111, 1625-1629. [CrossRef] [PubMed] 
46. Idavain, J.; Julge, K.; Rebane, T.; Lang, A.; Orru, H. Respiratory symptoms, asthma and levels of fractional exhaled nitric oxide in school children in the industrial areas of Estonia. Sci. Total Environ. 2019, 650, 65-72. [CrossRef]

47. Berhane, K.; Zhang, Y.; Linn, W.S.; Rappaport, E.B.; Bastain, T.M.; Salam, M.T.; Islam, T.; Lurmann, F.; Gilliland, F.D. The effect of ambient air pollution on exhaled nitric oxide in the Children's Health Study. Eur. Respir. J. 2011, 37, 1029-1036. [CrossRef] [PubMed]

48. Delfino, R.J.; Staimer, N.; Gillen, D.; Tjoa, T.; Sioutas, C.; Fung, K.; George, S.C.; Kleinman, M.T. Personal and ambient air pollution is associated with increased exhaled nitric oxide in children with asthma. Environ. Health Perspect. 2006, 114, 1736-1743. [CrossRef]

49. Permaul, P.; Gaffin, J.M.; Petty, C.R.; Baxi, S.N.; Lai, P.S.; Sheehan, W.J.; Camargo, C.A., Jr.; Gold, D.R.; Phipatanakul, W. Obesity may enhance the adverse effects of $\mathrm{NO}_{2}$ exposure in urban schools on asthma symptoms in children. J. Allergy Clin. Immunol. 2020, 146, 813-820.e2. [CrossRef]

50. Kobza, J.; Geremek, M.; Dul, L. Characteristics of air quality and sources affecting high levels of PM10 and PM2.5 in Poland, Upper Silesia urban area. Environ. Monit. Assess 2018, 190, 515. [CrossRef]

51. American Thoracic Society. Recommendations for standardized procedures for the on-line and off-line measurement of exhaled lower respiratory nitric oxide and nasal nitric oxide in adults and children-1999. This official statement of the American Thoracic Society was adopted by the ATS Board of Directors, July 1999. Am. J. Respir. Crit. Care. Med. 1999, 160, $2104-2117$.

52. Kim, H.B.; Eckel, S.P.; Kim, J.H.; Gilliland, F.D. Exhaled NO: Determinants and clinical application in children with allergic airway disease. Allergy Asthma Immunol. Res. 2016, 8, 12-21. [CrossRef]

53. Zhang, Q.; Wang, W.; Niu, Y.; Xia, Y.; Lei, X.; Huo, J.; Zhao, Q.; Zhang, Y.; Duan, Y.; Cai, J.; et al. The effects of fine particulate matter constituents on exhaled nitric oxide and DNA methylation in the arginase-nitric oxide synthase pathway. Environ. Int. 2019, 131, 105019. [CrossRef] [PubMed]

54. Zhao, Z.; Chen, R.; Lin, Z.; Cai, J.; Yang, Y.; Yang, D.; Norback, D.; Kan, H. Ambient carbon monoxide associated with alleviated respiratory inflammation in healthy young adults. Environ. Pollut. 2016, 208, 294-298. [CrossRef] [PubMed]

55. Delfino, R.J.; Staimer, N.; Tjoa, T.; Gillen, D.L.; Schauer, J.J.; Shafer, M.M. Airway inflammation and oxidative potential of air pollutant particles in a pediatric asthma panel. J. Exp. Sci. Environ. Epidemiol. 2013, 23, 466-473. [CrossRef]

56. Delfino, R.J.; Staimer, N.; Tjoa, T.; Arhami, M.; Polidori, A.; Gillen, D.L.; George, S.C.; Shafer, M.M.; Schauer, J.J.; Sioutas, C. Associations of primary and secondary organic aerosols with airway and systemic inflammation in an elderly panel cohort. Epidemiology 2010, 21, 892-902. [CrossRef] [PubMed]

57. Liu, L.; Poon, R.; Chen, L.; Frescura, A.M.; Montuschi, P.; Ciabattoni, G.; Wheeler, A.; Dales, R. Acute effects of air pollution on pulmonary function, airway inflammation, and oxidative stress in asthmatic children. Environ. Health Perspect. 2009, 117, 668-674. [CrossRef]

58. Maikawa, C.L.; Weichenthal, S.; Wheeler, A.J.; Dobbin, N.A.; Smargiassi, A.; Evans, G.; Liu, L.; Goldberg, M.S.; Pollitt, K.J. Particulate oxidative burden as a predictor of exhaled nitric oxide in children with asthma. Environ. Health Perspect. 2016, 124, 1616-1622. [CrossRef]

59. Chen, X.; Liu, F.; Niu, Z.; Mao, S.; Tang, H.; Li, N.; Chen, G.; Liu, S.; Lu, Y.; Xiang, H. The association between short-term exposure to ambient air pollution and fractional exhaled nitric oxide level: A systematic review and meta-analysis of panel studies. Environ. Pollut. 2020, 265, 114833. [CrossRef]

60. MacIntyre, E.A.; Gehring, U.; Mölter, A.; Fuertes, E.; Klümper, C.; Krämer, U.; Quass, U.; Hoffmann, B.; Gascon, M.; Brunekreef, B.; et al. Air pollution and respiratory infections during early childhood: Ananalysis of 10 European birth cohorts within the ESCAPE Project. Environ. Health Perspect. 2014, 122, 107-113. [CrossRef] [PubMed]

61. Zhang, X.; Fan, Q.; Bai, X.; Li, T.; Zhao, Z.; Fan, X.; Norbäck, D. Levels of fractional exhaled nitric oxide in children in relation to air pollutionin Chinese day care centres. Int. J. Tuberc. Lung Dis. 2018, 22, 813-819. [CrossRef] [PubMed]

62. Steerenberg, P.A.; Nierkens, S.; Fischer, P.H.; van Loveren, H.; Opperhuizen, A.; Vos, J.G.; van Amsterdam, J.G. Traffic-related air pollution affects peak expiratory flow, exhaled nitric oxide, and inflammatory nasal markers. Arch. Environ. Health. 2001, 56, 167-174. [CrossRef] [PubMed]

63. Ricciardolo, F.L. Revisiting the role of exhaled nitric oxide in asthma. Curr. Opin. Pulm. Med. 2014, 20, 53-59. [CrossRef] [PubMed]

64. Adamkiewicz, G.; Ebelt, S.; Syring, M.; Slater, J.; Speizer, F.E.; Schwartz, J.; Suh, H.; Gold, D.R. Association between air pollution exposure and exhaled nitric oxide in an elderly population. Thorax 2004, 59, 204-209. [CrossRef] [PubMed]

65. Breton, C.V.; Byun, H.M.; Wang, X.; Salam, M.T.; Siegmund, K.; Gilliland, F.D. DNA methylation in the arginase-nitric oxide synthase pathway is associated with exhaled nitric oxide in children with asthma. Am. J. Respir. Crit. Care Med. 2011, 184, 191-197. [CrossRef] [PubMed]

66. Chan, G.C.; Fish, J.E.; Mawji, I.A.; Leung, D.D.; Rachlis, A.C.; Marsden, P.A. Epigenetic basis for the transcriptional hyporesponsiveness of the human inducible nitric oxide synthase gene in vascular endothelial cells. J. Immunol. 2005, 175, 3846-3861. [CrossRef] [PubMed]

67. Nhung, N.T.T.; Amini, H.; Schindler, C.; Kutlar Joss, M.; Dien, T.M.; Probst-Hensch, N.; Perez, L.; Künzli, N. Short-term association between ambient air pollution and pneumonia in children: A systematic review and meta-analysis of time-series and case-crossover studies. Environ. Pollut. 2017, 230, 1000-1008. [CrossRef] [PubMed]

68. Zu, K.; Shi, L.; Prueitt, R.L.; Liu, X.; Goodman, J.E. Critical review of long-term ozone exposure and asthma development. Inhal. Toxicol. 2018, 30, 99-113. [CrossRef] 
69. Niu, T.; Lv, C.; Yi, G.; Tang, H.; Gong, C.; Niu, S. Therapeutic effect of medical ozone on lumbar disc herniation. Med. Sci. Monit. 2018, 24, 1962-1969. [CrossRef]

70. Barraza-Villarreal, A.; Sunyer, J.; Hernandez-Cadena, L.; Escamilla-Nuñez, M.C.; Sienra-Monge, J.J.; Ramírez-Aguilar, M.; Cortez-Lugo, M.; Holguin, F.; Diaz-Sánchez, D.; Olin, A.C.; et al. Air pollution, airway inflammation, and lung function in a cohort study of Mexico City school children. Environ. Health Perspect. 2008, 116, 832-838. [CrossRef] [PubMed]

71. Nickmilder, M.; de Burbure, C.; Carbonnelle, S.; Dumont, X.; Bernard, A.; Derouane, A. Increase of exhaled nitric oxide in children exposed to low levels of ambient ozone. J. Toxicol. Environ. Health A 2007, 70, 270-274. [CrossRef]

72. Karakatsani, A.; Samoli, E.; Rodopoulou, S.; Dimakopoulou, K.; Papakosta, D.; Spyratos, D.; Grivas, G.; Tasi, S.; Angelis, N.; Thirios, A.; et al. Weekly personal ozone exposure and respiratory health in a panel of Greek school children. Environ. Health Perspect. 2017, 125, 077016. [CrossRef] [PubMed]

73. Altuğ, H.; Gaga, E.O.; Döğeroğlu, T.; Brunekreef, B.; Hoek, G.; Van Doorn, W. Effects of ambient air pollution on respiratory tract complaints and airway inflammation in primary school children. Sci. Total Environ. 2014, 479-480, 201-209. [CrossRef] [PubMed]

74. Barath, S.; Mills, N.L.; Ädelroth, E.; Olin, A.-C.; Blomberg, A. Diesel exhaust but not ozone increases fraction of exhaled nitric oxide in a randomized controlled experimental exposure study of healthy human subjects. Environ. Health 2013, 12, 36. [CrossRef] [PubMed]

75. Laoudi, Y.; Nikasinovic, L.; Sahraoui, F.; Grimfeld, A.; Momas, I.; Just, J. Passive smoking is a major determinant of exhaled nitric oxide levels in allergic asthmatic children. Allergy 2010, 65, 491-497. [CrossRef] [PubMed]

76. Kougias, M.; Vardavas, C.I.; Anagnostopoulos, N.; Matsunaga, Y.; Tzwrtzi, A.; Lymberi, M.; Connolly, G.N.; Behrakis, P.K. The acute effect of cigarette smoking on the respiratory function and FENO production among young smokers. Exp. Lung Res. 2013, 39, 359-364. [CrossRef] [PubMed]

77. Traczyk, P.; Gruszecka-Kosowska, A. The condition of air pollution in Kraków, Poland, in 2005-2020, with health risk assessment. Int. J. Environ. Res. Public Health 2020, 17, 6063. [CrossRef] [PubMed]

78. Bokwa, A. Environmental impacts of long-term air pollution changes in Krakow, Poland. Pol. J. Environ. Stud. 2008, 17, 673-686. 